\title{
Just a little something
}

\author{
S Hancocks, OBE*
}

\section{Yes, it's holiday time again, and bravo for that, but every silver lining had a cloud, in the case of 'going away' it's a question of 'bringing something.'}

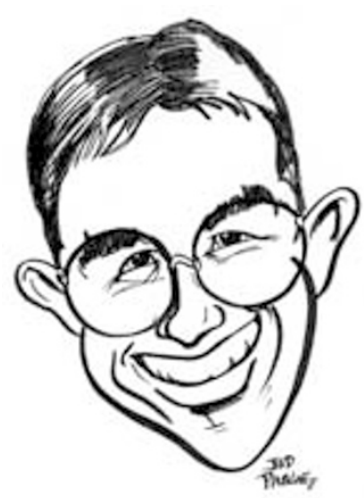

Sociologists or anthropologists could doubtless tell us why we feel the urge to bring something back. It's probably very practical, based on survival or courtship or eating, the three activities which seem to best separate us out from plants. Or it may be symptomatic of an ancient need to return with trophies; shrunken heads or trunks o'er brimming with booty. Alternatively it could be rooted in a deep desire just to show off that you've had the nouse to get up off your backside and travel outside the usual run of home, work, home, shops, home, bowling alley, shops and so forth.

Whatever the thesis-ladened background, it still leaves us with the contemporary sublimation of the problem. What exactly should we bring back from holiday to 'share' with our team members?

The difficulty, as ever, is finding something that pleases everybody and in which they can all share. Food is often a good starting point, although with the problems over the spread of viruses and other nasties, attempting to transport fresh produce is a complete nightmare. One has visions of being singled out by the food immigration police and led away as the others in the queue for baggage reclaim are left tutting and whispering speculatively about drug dealing and narcotics smuggling. In fact, all you've actually done is bring back a washed lettuce that you didn't have a chance to fully drain in your self-catering caravanette. Besides, being sniffed at Manchester airport is not everyone's idea of the perfect end to a relaxing break in the sun.

So the choice is narrowed down to consumables that are already in pots, jars, boxes, wrappers or bottles. Local specialities are a good thought as they nurture that particular ethnicity so otherwise difficult to track down. However this spells trouble if the regional delicacy turns out to be pickled sheeps' eyes, marinated termites or even something as innocuous as eucalyptus-blossom honey. How do you share that one out in the staff room on Monday morning - a line of bread sol- diers and a dip each with your coffee? Then again, dentistry has an added gauntlet to toss down; how can you take back sweets? Sweets are the obvious choice for work colleagues in every other field of endeavour. No problem for office employees, those on the factory floor, assembly line workers, bus drivers or the complete panoply of labourers and toilers in any other sort of business, but sweets in a dental practice absolutely not - what if the patients see? Some try to get round the embargo of course, disguising the offering

\section{There is just one} salvation - drive out to a small rural post office and snap up a dusty, fake-ivory figure of something indistinct, an

\section{unexplained feature of many such an emporium.}

as not really 'bad' for you. Chocolate covered plums for example are literally stuffed full of fruit, lightly fragranced Turkish delight is virtually fat free and Latvian sugar mice leave you with that wonderfully useful short piece of string that formed the tail until you had sucked away its owner. Of all the consumables, you can do worse than tea bags. You know the sort of thing, an attractive, 'distressed' box tacked together by natives out of discarded plywood lobbed from a passing container ship. It comes complete with sachets of herbal infusions of rosehip, something unpronounceably Latin that looks like deadly nightshade and Empire breakfast tea. It's the sort of present that everyone tries one from before it gets consigned, by degrees, to the cupboard under the sink so as not to offend the purchaser. Such momentos are destined to be found years later, long after the intrepid traveller has left the practice. Held aloft and questioned as to their presence, the sole remembrance of the team member is distilled into a touching epitaph such as, 'oh that was old thingamyjig brought those back from whatjamacallit. Dump 'em.'

At the beginning of the holiday thoughts of what to take back hardly enter the consciousness. Ironically it is at that stage that you do see something that might be appropriate but, alas, one or two weeks later, you can't for the life of you remember where you saw it, or even what the dratted thing was. The ultimate dread is leaving it so late that you are standing in the souvenir shop at the airport still bereft of ideas. This is especially galling if it finds you wishing that you had let temptation get the better of you the previous day in the town square market and snapped up those tea towels printed with curious, slightly out-of-register colour pictures of fruit pancakes.

So, the airport shop or not? Well, there's not much choice. His and Hers paper kimonos are very 'individual' but may be construed as a tad too saucy, a battery operated, 24-hour non-stop personal radio - hmm? Then it is a descent into key fobs with local pressed flowers, fridge magnets saying 'I heart [insert name of airport] airport' or personalised ceramic door names - 'Naomi's room' and so forth.

Back at home with nothing to show, there is just one salvation - drive out to a small rural post office and snap up a dusty, fake-ivory figure of something indistinct, an unexplained feature of many such an emporium. 'Oh' everyone will say, not wanting to appear rude or, worse, ignorant, 'that's unusual'. 'Isn't it?' you'll reply, 'Unusual but charming. I got it on a local hike we did, just a little something.' Phew! 